\title{
Publisher Correction: Uncoupled phytoplankton-bacterioplankton relationship by multiple drivers interacting at different temporal scales in a high-mountain Mediterranean lake
}

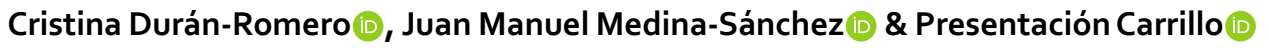

Correction to: Scientific Reports https://doi.org/10.1038/s41598-019-57269-y, published online 15 January 2020

The original version of this Article contained missing bar chart outlines and missing error bars in all figures.

Additionally, in Figure 1 the figure key was incorrect. The individual groups for "Crysophyceae", "Bacillariophyceae" and "Dinophyceae" are now in one group "Others".

As a result, the legend of Figure 1 was incorrect.

"Sestonic N:P ratio (on a molar basis), phytoplankton abundance (PA) and chlorophyll $a$ (Chl $a$ ) concentration under full sunlight (UVR + PAR) and photosynthetically active radiation (PAR) and under ambient phosphorus (P) concentration and $\mathrm{P}$-added conditions. Bars represent the mean values and error bars represent the standard deviation $(\mathrm{SD})(\mathrm{n}=3)$."

now reads:

"Sestonic N:P ratio (on a molar basis), phytoplankton abundance (PA) and chlorophyll a (Chl a) concentration under full sunlight (UVR + PAR) and photosynthetically active radiation (PAR) and under ambient phosphorus (P) concentration and P-added conditions. In Fig. 1b, Others group includes Cryptophyceae, Bacillariophyceae and Dinophyceae, and represents a small proportion of the total phytoplankton abundance. Bars represent the mean values and error bars represent the standard deviation $(\mathrm{SD})(\mathrm{n}=3)$."

This has now been corrected in the PDF and HTML versions of the original article.

(i) Open Access This article is licensed under a Creative Commons Attribution 4.0 International Cicense, which permits use, sharing, adaptation, distribution and reproduction in any medium or format, as long as you give appropriate credit to the original author(s) and the source, provide a link to the Creative Commons license, and indicate if changes were made. The images or other third party material in this article are included in the article's Creative Commons license, unless indicated otherwise in a credit line to the material. If material is not included in the article's Creative Commons license and your intended use is not permitted by statutory regulation or exceeds the permitted use, you will need to obtain permission directly from the copyright holder. To view a copy of this license, visit http://creativecommons.org/licenses/by/4.0/.

(C) The Author(s) 2020 